\title{
Intregasi Model Pembelajaran Pesantren Di Sekolah Formal: Studi Kasus Di SMP Islam As-Syafiah Mojosari Kec. Loceret Nganjuk
}

\author{
Dedik Muksinun Nafi, ${ }^{1}$ Wasito $^{2}$ \\ ${ }^{1}$ Pascasarjana Institut Agama Islam Tribakti Kediri, 2Institut Agama Islam Tribakti Kediri \\ ${ }^{1}$ dedik.nafi@gmail.com, 2azambagus8@gmail.com
}

\begin{abstract}
This research focuses on applying the concept of integration of pesantren learning models in schools. The location of this study in As-Syaf'iah Islamic School, Mojosari Kec. Loceret, Nganjuk. The selection of this concentration, as evidence from previous studies that are modeled. The purpose of this study is to describe the pesantren-based learning model implemented in the AsSyafi'ah Mojosari Islamic Middle School. To analyze aspects that contribute to the implementation of the pesantren based learning model in As-Syafi'ah Mojosari Islamic Middle School. This research uses a descriptive qualitative approach. This study uses interviews, observation and documentation as a way to explore data. The data that has been collected will be analyzed and described in accordance with research concentrations. The results of this study can be conveyed that the pesantren-based Learning model implemented in AsSyafi'ah Mojosari Islamic Middle School runs without changing the typical pesantren. All activities are carried out by all students who are also students in As-Syafi'ah Islamic Middle School. The smooth running of these activities is supported by the mandatory boarding program, so that supervision of all santri is very easy, moreover supported by the location of school buildings and dormitories in one area located in the middle of Ngepeh village. In addition to the mandatory boarding program there are also tahfidz and entrepreneurship programs. The tahfidz program in question is obligatory to memorize the Qur'an Juz 30 and it is recommended to memorize all the Qur'an.
\end{abstract}

Keywords: Integration, Learning Model, Boarding School

\begin{abstract}
Abstrak
Penelitiaan ini berfokus pada penerapan konsep integrasi model pembelajaran pesantren di skolah formal. Lokasi penelian ini di Sekolah Menengah Pertama (SMP) Islam As-Syaf'iah Mojosari Kec. Loceret, Nganjuk. Pemilihan konsen ini, sebagi pembuktian dari penelitian-penelitian terdahulu yang semodel. Tujuan penelitian ini untuk mendeskripsikan model pembelajaran berbasis pesantren yang diimplementasikan di SMP Islam As-Syafi'ah Mojosari. Untuk menganalisis aspek yang berkontribusi pada implementasi model pembelajaran berbasis pesantren di SMP Islam As-Syafi'ah Mojosari. Penelitian ini menggunakan pendekatan kualitiatif diskriptif. Penelitian ini menggunakan interview, observasi dan dokumnetasi sebagai cara untuk menggali data. Data yang sudah dikumpulkan akan dianalisis dan
\end{abstract}


didiskripsikan sesuai dengan konsen penelitian. Hasil penelitian ini dapat disampaikan bahwa model Pembelajaran berbasis pesantren yang di implementasikan di SMP Islam As-Syafi'ah Mojosari berjalan dengan tidak merubah khas pesantren. Semua kegiatan dilaksanakan semua santri yang juga menjadi peserta didik di SMP Islam As-Syafi'ah. Kelancaran kegiatan tersebut karena didukung dengan program wajib mondok, sehingga pengawasan terhadap semua santri sangat mudah apalagi didukung dengan lokasi gedung sekolah dengan gedung asrama dalam satu wilayah yang terletak di tengah desa Ngepeh. Selain program wajib mondok juga ada program tahfidz dan kewirausahaan. Program tahfidz yang dimaksud adalah wajib hafal al-Qur'an Juz 30 dan dianjurkan untuk menghafal semua alQur'an

Kata Kunci: Integrasi, Model Pembelajaran, Pesantren

\section{Pendahuluan}

Dalam sejarah perkembangan pendidikan di Indonesia, Pendidikan Agama Islam (PAI) menjadi kebutuhan banyak kalangan untuk mengawal perkembangan perilaku siswa. Berbagai formasi metode dan strategi terus dikembangkan untuk dintregasikan dengan pendidikan lainnya sebagai langkah strategis mencapai tujuan pendidikan nasional. Untuk itu, integrasi pembalajaran menjadi kebutuhan para penyelenggara pendidikan jika ingin mencapai tujuan pendidikan nasional. dalam konteks ini, sangat menarik untuk membahas model integrasi pembelajaran pendidikan di pondok pesantran.

Istilah integrasi sendiri berasal dari bahasa Inggris yaitu integrate. Dalam buku The Contemprorary English istilah integrate (vt) integrated, integrating, integrates diterjemahkan menjadi menggabungkan; menyatu-padukan; mengintegrasikan; sedangkan integrated (adj) diterjemahkan menjadi dapat bergaul dengan dasar yang sama, terpadu. Secara umum, tujuan utama integrasi adalah agar kultur positif yang berkembang di pesantren dapat diadopsi oleh sekolah dan bisa diterapkan ke dalam berbagai aspek proses pendidikan di sekolah, termasuk dalam proses pembelajaran dan manajemen sekolah.

Sejatinya, Pondok Pesantren merupakan lembaga pendidikan tertua di Indonesia, didirikan karena adanya tuntutan dan kebutuhan zaman. Menurut ahli pendidikan, pesantren merupakan produk pendidikan asli Indonesia. Hal ini bisa dilihat dari perjalanan sejarahnya di Indonesia. Pesantren dilahirkan atas kesadaran kewajiban dakwah Islamiyah, yakni menyebarkan dan mengembangkan ajaran Islam sekaligus mencetak generasi, kader-kader tokoh agama, dan 
ulama dan yang memperjuangakan nilainilai kemanusiaan. ${ }^{1}$

Namun semenjak Belanda memerintah Indonesia, pendidikan Islam mengalami banyak hambatan, bahkan dikatakan zaman kemunduran. Hal ini disebabkan karena kebijakan pemerintah yang cenderung memberatkan, misalnya Tahun 1755 Tanah Lungguh yang dijadikan sebagai tempat belajar semua harus dihapuskan dan dijadikan tanah pemerintahan (Gubernemen), sejak perjanjian Gianti. Kemudian tahun 1900 Belanda menghilangkan pengajaran sistem pesantren, diganti dengan sistem kelas atau sekolah. Hal ini dengan dalih politik. ${ }^{2}$ Akibatnya, pesantren kehilangan kekhasan dalam sistem pembelajaran. Masyarakat pun akhirnya tidak banyak mengenal pesantren, akan tetapi mengenal sekolah dengan perspektif Kolonial.

Antara sekolah dan Pesantren mempunyai tujuan sama, namun berbeda dalam pengelolaannya. Banyak masyarakat yang tidak memahami. Bahkan saat ini banyak masyarakat masih ada yang beranggapan bahwa pesantren tidak bisa menjamin masa depan anak dalam hal pekerjaan, sehingga sebagian masyarakat memandang sebelah pada pendidikan pesantren dan lebih mengutamakan pendidikan sekolah untuk menyekolahkan anak. Hal ini menjadikan hambatann terbesar dalam perkembangan pondok pesantren. Di samping itu juga adanya aturan pemerintah tentang wajib belajar di sekolah pada tingkatan dasar dan menengah. Semakin menjadikan pesantren pilihan kedua bagi masyarakat.

Hambatan tersebut, menjadikan pesantren harus melakukan berbagai upaya mengelola keinginan pasar (masyarakat). Hasilnya dapat ditemukan, saat ini banyak pesantren yang mengadopsi pendidikan formal untuk menjawab tantangan tersebut. Dengan tujuan agar tradisi pendidikan pesantren tetap terjaga dan mampu mencetak generasi yang siap bersaing di bidang ilmu pengetahuan dan teknologi yang sesuai pada zamannya.

Model pemikiran inipun, sejatinya menambah nilai positif bagi pendidikan khas Indonesia. Keberadaan sekolah formal yang di bawah naungan pesantren justru memberikan kontribusi yang sangat besar terhadap bangsa dan negara, terbukti banyak lulusan sekolah yang berbasis pesantren berpengaruh positif di tengah masyarakat. Begitu pula harapan dari SMP Islam As-Syafi'ah Mojosari yang baru berdiri 4 tahun ini.

Dari uraian diatas penulis menysusn artikel berdasarkan penelitian di Sekolah Menengah Pertama (SMP) Islam As-Syafi'ah Mojosari, Mojokerto. Tujuan penelitian ini memahami lebih mendalam konsep dan penerapan integrasi yang dilaksanakan di Pesantren SMP Islam As-Syafi' ah Loceret, Mojosari. Mojokerto"
${ }^{1}$ Hasbulloh, Kapita Selekta Pendidikan Islam, (Jakarta: PT. Raja Grafindo Persada, 1999), h,40
2 Wahyoetomo, Perguruan Tinggi Pesantren (Pendidikan Alternatif Masa Depan), (Jakarta: Gema Insani Press, 1997), $h, .76$ 


\section{Metode}

Penelitian ini menggunakan pendekatan kualitatif, yaitu suatu proses penelitian yang dilakukan secara wajar dan natural sesuai dengan kondisi objektifdi lapangan tanpa adanya manipulasi. Lokasi Penelitian ini bertempat di SMPI As-Syafi'ah Mojosari yang merupakan lembaga yang berdiri dibawah naungan Pondok pesantren AlMardiyah Mojosari.

Dalam teknik pengumpulan data dipergunakan berbagai teknik, yaitu wawancara, observasi dan dokumentasi. Sasaran informan adalah narasumber yang mengelola atau yang bersinggungan dengan pondok pesantern tersebut. Ketiga teknik tersebut dipergunakan untuk memperoleh data dan informasi yang saling menunjang dan melengkapi tentang implementasi model pembelajaran berbasis pesantren di SMP Islam As-Syafi'ah Mojosari.

\section{Kajian Teoritik}

\section{Integrasi Dalam Pendidikan}

Istilah Integrasi dalam dunia pendidikan seringkali diartikan sebagai sebuah peleburan menjadi satu kesatuan yang utuh. Sedangkan menurut Kamus Besar Indonesia, integrasi adalah menjadi pembaharuan menjadi satu kesatuan yang utuh atau bulat. ${ }^{3}$ Konsep ini semakin sering dipakai dalam dunia pendidikan untuk mencari formula dalam penyelenggaraan pendidikan.

Dalam Bahasa Indonesia, kata model berarti sebagai pola (contoh, acuan, ragam) sedangkan dalam bahasa inggris kata model memiliki beberapa pengertian, kata model dipandang sebagai kata benda (noun), berikut ini model dapat diklasilifikasikan sebagai berikut:

1. Model deskriptif, hanya menggambarkan situasi sebuah sistem tanpa rekomendasi dan peramalan

2. Model prediktif, model ini menunjukan apa yang akan terjadi, bila sesuatu terjadi.

3. Model normatif, model ini menyediakan jawaban terbaik terhadap satu persoalan. Model ini memberi rekomendasi tindakantindakan yang perlu diambil.

Berdasarkan kajian di atas, integral dapat didefinisikan suatu perencanaan atau suatu pola yang digunakan sebagai pedoman dalam merencanakan pembelajaran di kelas atau pembelajaran dalam totarial. Maupun pola dalam berbagai hal seperti pola dalam pengintegrasian lembaga pendidikan guna meningkatkan mutu pembelajaran.

Konsep dasar integral, bisa dilihat dalam pemikiran sosiolog klasik Dahrendrof Ralf Dahrendrof. Menurutnya, teori model Intgrasi dapat digunakan untuk melihat masyarakat, karena dalam sejarahnya masyarakat

${ }^{3} \mathrm{M}$. Khairir, Integrasi metode Sarongan dan Bandongan dalam meningkatkan kreativitas belajar dipondok pesantren Aswaja-Mlangi-

Sleman, Yogyakarta) (Yogyakarta: Universitas Islam Negeri,2013), h. 9 
selalu berusaha mengintegrasikan satu komponen dengan komponen lain yang ada dalam masyarakat. Diantara pokok pemikiran Dahrendrof antara lain:

Pertama Setiap masyarakat secara relatif bersifat langgeng, maksudnya masyarakat pada hakikatnya memilki ikatan kekeluargaan yang kuat, kenapa karena masyarakat yang hidup di suatu daerah tertentu memiliki adat ataupun tradisi tersendiri sehingga membuat masyarakat tersebut saling menjaga dan membantu. Kedua setiap masyarakat merupakan Struktur elemen yang terintegrasi dengan baik. Ketiga setiap elemen dalam suatu masyarakat memilki satu fungsi, yaitu menyumbang pada bertahannya sistem itu. Keempat setiap struktur sosial yang berfungsi didasarkan pada konsensus nilai diantara para anggotanya. Konsensus merupakan kesepakatan bersama antara bagian-bagian yang ada dalam keseluruhan masyarakat. ${ }^{4}$

\section{Kajian Model Pembelajaran}

Setiap model pembelajaran memiliki ciri-ciri yang dapat mempengaruhi proses pembelajaran. Gunter mendefinisikan an instructional model is a step-by-step procedure that leads to specific learning outcomes. Joyce \& Weil mendefinisikan model pembelajaran

4 Wirawan, "Teori-teori sosial dalam tiga paradikma fakta sosial,definisi sosial,perilaku sosial," (Jakata:kencana prenada media Grouph, 2012).4547

${ }^{5}$ Gunter, M. A., Estes, T. H., \& Schwab, J. Instruction: A models approach. Boston: Allyn and Bacon (1990). sebagai kerangka konseptual yang digunakan sebagai pedoman dalam melakukan pembelajaran. ${ }^{5}$ Dengan demikian, model pembelajaran merupakan kerangka konseptual yang melukiskan prosedur yang sistematis dalam mengorganisasikan pengalaman belajar untuk mencapai tujuan belajar. Jadi model pembelajaran cenderung preskriptif, yang relatif sulit dibedakan dengan strategi pembelajaran. An instructional strategy is a method for delivering instruction that is intended to help students achieve a learning objective. ${ }^{6}$

Dalam penerapnnya, untuk mencapai tujuan pembelajaran, model pembelajaran harus didukung oleh lingkungan belajar dan perilaku setiap siswa yang ikut dalam proses pembelajaran tersebut. Adapun ciri-ciri model pembelajaran antara lain: a. Rasional teoretik logis yang disusun oleh para pencipta atau pengembangannya. $b$. Landasan pemikiran tentang apa atau bagaimana siswa belajar (tujuan pembelajaran yang akan dipakai). c. Tingkah laku belajar yang diperlukan agar model tersebut dapat dilaksanakan dengan berhasil. d. Lingkungan belajar yang diperlukan agar tujuan pembelajaran itu dapat tercapai. ${ }^{7}$

Model pembelajaran pada dasarnya merupakan bentuk pembelajaran

6 Burden, P. R., \& Byrd, D. M. Method for effective teaching, second edition. Boston: Allyn and Bacon 1996.

7 Triatno, Mendesain Model Pembelajaran Inovatif-Progresif, (Jakarta: Kencana, 2011), h, . 6 
yang tergambar dari awal sampai akhir yang disajikan secara khas oleh guru. Dengan kata lain, model pembelajaran merupakan bungkus atau bingkai dari penerapan suatu pendekatan, metode, dan teknik pembelajaran. Berkenaan dengan model pembelajaran, Bruce Joyce dan Marsha Weil Dedi Supriawan dan A. Benyamin Surasega, mengetengahkan 4 (empat) kelompok model pembelajaran, yaitu: (1) model interaksi sosial; (2) model pengolahan informasi;

(3) model personal-humanistik; dan (4) model modifikasi tingkah laku. ${ }^{8}$

\section{Tinjauan tentang Pesantren}

Peraturan Menteri

Agama

Republik Indonesia Nomor 13 Tahun 2014 tentang Pendidikan keagamaan Islam menjelaskan tentang pesantren. Dalam paragraf 1 ayat 1 berbunyi, pesantren sebagai kesatuan pendidikan yang merupakan pesantren yang menyelengarakan pengajian kitab kuning atau dirasah islamiah dengan pola pendidikan mu'allimin. Ayat ini secara tegas menjelaskan bahwa pesantren menjadi bagian penyelenggaraan pendidikan yang diakui oleh pemerintah Negara Republik Indonesia (NRI). Akan tetapi pelaksanaannya harus menerapkan prinsip integral sebagaimana yang ditegaskan pada ayat 3 berbunyi penyelengaraan dirasah islmiyah dengan pola pendidikan $m u^{\prime}$ allimin sebagaimana

\footnotetext{
${ }^{8}$ Dedi Suprawan dan A. Benyamin
} Surasega, $(1990)<$ Strategi Belajar Mengajar, Diktat Kuliah, FPTK-IKIP : Bandung,

${ }^{9}$ https:// www.e-dokumen.kemenag.go.id. dimaksud pada ayat 1 dilakukan secara integratif dengan memadukan ilmu agama islam dan ilmu umum dan bersifat komprehensif dengan memadukan itra, ekstra, kurikuler. ${ }^{9}$

Pengertian Pesantren menurut sebagian ahli berasal dari kata santri, yaitu pesantrian atau dikenal tempat tinggal santri. Keberadaan pesantren tidak terlepas dari perkembangan masuknya Islam di Indonesa. Meski demikian, para ahli berpendapat, patokan untuk mengambarkan dinamika pesantren berpatokan pada pertama kali pesantren yang didirikan oleh Maulana Malik Ibrahim pada Tahun 1399 M.

Istilah Pondok Pesantren merupakan dua istilah yang menunjukkan satu pengertian. Pesantren menurut pengertian dasarnya adalah tempat belajar para santri, sedangkan pondok berarti rumah atau tempat tinggal sederhana terbuat dari bambu. Di samping itu, kata pondok mungkin berasal dari Bahasa Arab Funduq yang berarti asrama atau hotel. Di Jawa termasuk Sunda dan Madura umumnya digunakan istilah pondok dan pesantren, sedang di Aceh dikenal dengan istilah dayah atau rangkang atau menuasa, sedangkan di Minangkabau disebut surau. ${ }^{10}$

Pondok merupakan tempat penampungan sederhana bagi pelajar yang jauh dari asalnya. Merupakan

10 Zamakhsyari Dhofier, (1982), Tradisi Pesantren (Studi Pandangan Hidup Kyai dan Visinya mengenai Masa Depan Indonesia,, Jakarta, LP3ES), h, .18 
tempat tinggal Kiai bersama santrinya dan bekerjasama untuk memenuhi kehidupan sehari-hari. Pondok bukanlah semata-mata dimaksudkan sebagai tempat tinggal atau asrama santri untuk mengikuti pelajaran yang diberikan oleh kiai, melainkan juga sebagai tempat latihan bagi santri untuk hidup mandiri. Lebih jelas dan sangat terinci sekali Nurcholish Madjid mengupas asal usul kata santri, dan juga tentang kiai karena kedua perkataan tersebut tidak dapat dipisahkan ketika membicarakan tentang pesantren. Ia berpendapat: santri asal kata sastri (sansekerta) yang berarti melek huruf, dikonotasikan dengan santri adalah kelas literary, pengetahuan agama dibaca dari kitab berbahasa Arab dan diasumsikan bahwa santri berarti juga orang yang tahu tentang agama (melalui kitab-kitab) dan paling tidak santri bisa membaca Al Qur'an, sehingga membawa kepada sikap lebih serius dalam memandang agama. Perkataan santri juga berasal dari bahasa Jawa cantrik yang berarti orang yang selalu mengikuti seorang guru kemana guru pergi menetap (ingat pada pewayangan), tentu dengan tujuan dapat belajar dari guru mengenai suatu keahlian. Cantrik dapat diartikan juga orang yang menumpang hidup atau ngenger (Jawa). Termasuk orang yang dating menumpang dirumah orang lain yang mempunyai sawah dan ladang untuk ikut menjadi buruh tani

11 Nurcholis Madjid,, Bilik-Bilik Pesantren Sebuah Potret Perjalanan, (Jakarta: Paramadina. 1997), h, . 5 juga disebut santri, tentu juga berasal dari perkataan cantrik. ${ }^{11}$

\section{Sistem Pendidikan Pondok Pesantren}

Pendidikan bagi umat manusia merupakan sistem dan cara meningkatkan kualitas hidup dalam segala bidang dan sesuai dengan perkembangan serta kemajuan zaman karena saat sekarang kita berada dalam era globalisasi yang serba canggih dengan perkembangan teknologi yang begitu pesat. Sehingga untuk meningkatkan kualitas hidup pondok pesantren harus selalu berproses menuju kerah yang lebih baik dengan meningkatkan kualitasnya.

Sistem merupakan suatu keseluruhan komponen yang masing-masing bekerja dalam fungsinya. Berkaitan dengan fungsi dari komponen lainnya yang secara terpadu bergerak menuju kearah satu tujuan yang telah ditetapkan. Komponen yang bertugas sesuai dengan fungsinya, bekerja antara satu dengan lainnya dalam rangkaian satu sistem. Sistem yang mampu bergerak secara terpadu bergerah ke arah tujuan sesuai dengan fungsinya. Sistem pendidikan adalah satu keseluruhan terpadu dari semua satuan dan kegiatan pendidikan yang berkaitan dengan yang lainnya, untuk mengusahakan tercapainya tujuan pendidikan. ${ }^{12}$

Sedangkan dalam pesantren dengan pola hidup bersama antara santri dengan kiai dan masjid sebagai pusat

12 H.M. Arifin, Kapita Selekta Pendidikan Islam, (Jakarta: Bumi Aksara, 2003), h, . 72 
aktifitas merupakan suatu sistem pendidikan yang khas yang tidak ada dalam lembaga pendidikan lain. Keunikan lain yang terdapat dalam sistem pendidikan pesantren adalah tentang metode pengajarannya sebagai berikut:

\section{Sorogan}

Kata sorogan berasal dari bahasa Jawa sodoran atau yang disodorkan artinya suatu sistem belajar secara individu dimana seorang santri berhadapan dengan seorang guru, terjadi interaksi saling mengenal diantara keduanya. ${ }^{13}$ Seorang kiai atau guru menghadap satu persatu, secara bergantian.

Sedangkan dalam pelaksanaannya, santri datang secara bersama-sama, akan tetapi para santri antri menunggu gilirannya. Sistem sorogan ini menggambarkan bahwa kiai dalam memberikan pengajarannya senantiasa berorientasi pada tujuan, selalu berusaha agar santri yang bersangkutan dapat membaca, mengerti dan mendalami isi kitab.

Dengan adanya suatu sistem pengajaran dengan sorogan ini seorang kiai mampu mengevaluasi langsung kemampuan santri, dan hubungan antara santri dan kiai lebih dekat.

\section{Wetonan}

Istilah wetonan berasal dari bahasa Jawa yang artinya berkala dan berwaktu. Wetonan ini merupakan suatu bentuk rutin harian, akan tetapi dilaksanakan pada saat-saat tertentu. Misalnya dilaksanakan pada setiap hari Jum'at, sholat shubuh dan sebagainya. Kiai membaca kitab dalam waktu tertentu dan santri dengan membawa kitab yang sama mendengar dan menyimak bacaan Kiai itu. Tidak ada ketentuan absensi, sehingga santri bisa datang atau tidak.

Dalam hal ini dapat dikatakan bahwa sistem pengajaran dipondok itu bebas, bebas untuk belajar dan tidak belajar. ${ }^{14}$ Dalam sistem pengajaran ini apa yang dibaca Kiai tidak dapat dipastikan karena kadang kitab tidak ditentukan dan terkadang pula ditentukan. Sedangkan dalam penyampaiannya kepada santri bermacam-macam, ada yang dengan diberi makna dan ada juga yang diartikan bebas. ${ }^{15}$

\section{Bandongan}

Dalam sistem bandongan ini bisa juga disebut halaqoh yang dalam pengajarannya, kitab yang dibacakan kiai dan yang dibawa oleh santri adalah sama, kemudian santri mendengarkan dan menyimak bacaan sang guru. ${ }^{16}$ Ketiga pola pengajaran tersebut diatas ini dapat berlangsung tergantung pada otoritas seorang kiai baik yang berkaitan dengan waktu, tempat, materi pelajaran dalam proses belajar mengajar.
13 Hasbullah, (1996), Sejarah Pendidikan Islam Indonesia, (Jakarta: PT. Grafindo Persada, 1996),. h, 50
14 Mukti Ali, Beberapa Persoalan Agama Dewasa Ini, (Jakarta: Rajawali Press, 1987) , h, .19

${ }^{15} \mathrm{Ibid}, \mathrm{h}, .52$

${ }^{16} \mathrm{Ibid}, \mathrm{h}, .51$ 
Dalam perkembangan selanjutnya, untuk mempermudah proses pembelajaran maka diterapkan suatu sistem madrasah dan klasikal sebagai bentuk pengembangan dan pembaharuan dari ketiga metode tersebut diatas. Perkembangan ini dapat dijumpai hampir diseluruh pesantren sekarang, selain sistem madrasah, klasikal, diniyah, denagn perjenjangan dan evaluasi yang jelas dan terstruktur.

Namun demikian, bukan berarti lantas ditinggalkan karena tidak efektif. Akan tetapi metode-metode dalam pembelajaran harus selalu mempertimbangkan tingkat pencapaian hasil belajar siswa dengan bukti memiliki efektifitas yang tinggi. kelebihan dari metode sorogan adalah memungkinkan seorang kiai atau ustadz mengawasi, menilai dan membimbing secara maksimal kemampuan seorang santri dalam menguasai materi. Sedangkan tingkat efektifitas bandongan adalah terletak pencapaian kuantitas dan percepatan kajian kitab, selain juga untuk tujuan kedekatan relasi santri, kyai atau ustadz. Secara teoritis, harus diakui bahwa setiap metode memiliki kelebihan dan kelemahan masing-masing.

Dari uraian diatas dapat diketahui tentang penyelenggaraan system pendidikan di pondok pesantren dewasa ini dapat digolongkan:

Pertama, Pondok pesantren adalah lembaga pendidikan dan pengajaran agama Islam, yang pada umumnya pendidikan dan pengajaran diberikan dengan cara non klasikal (bandongan dan sorogan), dimana seorang kiai mengajar santrinya berdasarkan kitab-kitab yang ditulis pada abad pertengahan, sedang santri biasanya tinggal di asrama atau pondok;

Kedua, Pondok pesantren adalah lembaga pendidikan dan pengajaran agama Islam yang ada pada dasarnya sama dengan pondok pesantren diatas, tetapi para santrinya tidak disediakan pondokan (komplek), namun tinggal tersebar di seluruh penjuru desa sekeliling pesantren tersebut (santri kalong) dimana cara dan metode pendidikan dan pengajaran agama Islam diberikan dengan sistem wetonan;

Ketiga, Pondok pesantren dewasa ini merupakan lembaga gabungan antara sistem pondok pesantren yang memberikan pendidikan dan pengajaran agama Islam dengan sistem bandongan dan sorogan kepada santri, disediakan pondokan ataupun merupakan santri kalongan yang dalam istilah pendidikan pondok modern memenuhi criteria non formal, serta menyelenggarakan pula pendidikan formal berbentuk madrasah dan bahkan sekolah umum dalam berbagai tingkatan dan aneka kejuruan menurut kebutuhan masyarakat masingmasing. ${ }^{17}$

Berdasarkan tiga bentuk sistem pendidikan diatas, pada kenyataannya 
sistem yang ketiga saat sekarang banyak bermunculan dan berkembang sebagai bentuk respon atas tuntutan perkembangan zaman dan ilmu pengetahuan teknologi era globalisasi. Perpaduan sistem tradisional dan modern berusaha menemukan solusi atas kelemahan dan kekurangan masing-masing.

Sedangkan menurut Mukti Ali sistem pendidikan dan pengajaran Islam di Indonesia ini yang paling baik adalah sistem pendidikan yang mengikuti sisitem pondok pesantren, sedang pengajarannya mengikuti sistem madrasah, dengan kata lain madrasah dalam pondok pesantren adalah bentuk pengajaran dan pendidikan Islam yang paling baik. ${ }^{18}$

\section{Hasil Penelitian}

Model Pembelajaran berbasis pesantren yang diimplementasikan di SMP Islam As-Syafi'ah Mojosari. Model pembelajaran berbasis pesantren yang diterapkan di SMP Islam As-Sayafi'iah pertama, semua peserta dianggap menjadi santri di pondok pesantren dengan sistem pembelajaran ala pesantren. Santri yang tinggal di pesantren tidak akan terpengaruh dengan budaya negatif yang menjalar pada kehidupan remaja zaman sekarang ini. Kedua, Semua santri dialarang membawa HP, ,sehingga dampak negatif dari HP tidak akan mempengaruhi santri. Santri berada di lingkungan yang sangat kental dengan budaya pesantren yang nota bene menjunjung tinggi budaya-budaya agama Islam. Ketiga, karena besarnya urgensi shalat berjamaah bagi keumuman lingkungan kaum muslimin dan bagi setiap siswa di SMP Islam AsSyafi'ah wajib berjamaah. Selain santri terbiasa dengan sholat Jama'ah, santri juga terbiasa membaca al-Quran yang manfaatnya sangat besar. Karena santri di SMP Islam As-Syafi'ah mengikuti sorogan al-Qur'an tiga kali dalam sehari, yaitu setelah jama'ah Shubuh, Ashar, dan Maghrib.

Adapun sejumlah hal yang memperkuat sistem pondok pesantren di SMP Islam As-Syafi'ah. Pertama, Pondok Pesantren menekankan pendidikan dengan basis mengharus utamakan kecerdasan spiritual (SQ) di samping kecerdasan intelektual (IQ dan emosional (EQ) bagi para santri. Sehingga para santri akan memiliki kecerdasan dan karakter yang kuat dan mudah bersosialisasi di masyarakat. Hal ini yang menyebabkan para santri lebih mudah diterima dan bermanfaat di tengahtengah masyarakat.

Kedua, Pondok Pesantren merupakan lembaga pendidikan tertua di bumi nusantara ini yang didirikan oleh para wali, kyai dan penyebar Agama Islam yang melakukan tafaqquh fi AlDiin dengan Ikhlas. Mereka adalah orang-orang yang bersih batinnya dan selalu mendekatkan diri kepada Allah. Hal ini yang menyebabkan Ilmu yang 
diperoleh di Pondok Pesantren menjadi lebih berkah.

Saat ini kita sedang khawatir dari beragam pengaruh negatif yang ada di tengah-tengah masyarakat. Narkoba, pergaulan bebas, kenakalan remaja, dan lain sebagainya sedang mengancam teman, tetangga bahkan keluarga kita sendiri. Nah, di Pondok Pesantren dengan pengawasan penuh dari Kyai, Guru-guru dan Pengurus Pondok Pesantren, santri sepenuhnya bisa dikontrol dan dilindungi dari pengaruh negatif tersebut. Dengan pendidikan berbasis nilai-nilai Islam Nusantara, Pondok Pesantren menjadi lembaga yang memiliki daya tahan (imun) dari berbagai ancaman pengaruh negatif.

Pondok Pesantren akan menghasilkan alumni santri yang memiliki solidaritas berbasis Islam yang kuat. Hidup bersama tunggal liwet, tunggal bancik selama bertahun-tahun telah membentuk santri menjadi pribadi yang memiliki rasa solidaritas dengan sesama. Santri akan mampu mengintegrasikan ilmu yang didapat melalui madrasah formal dengan ilmu agama yang didapat melalui pendidikan pesantren dengan kitab kuning-nya dalam kehidupan sehari-hari. Ilmu inilah yang akan memudahkan para santri untuk memahami makna hidup yang sesungguhnya. Hidup mandiri, terpisah dari orang tua, fasilitas apa adanya, akan membentuk santri sebagai muslim yang bertanggung jawab dan terbiasa memotivasi dirinya sendiri untuk lebih baik.
Sebagai lembaga pendidikan unggulan, Pondok Pesantren mampu melakukan pembentukan karakter Muslim Nusantara yang sesuai dengan ajaran Islam yang berpadu dengan nilainilai tradisi, budaya dan kearifan lokal pada semua sisi kehidupan, sehingga melahirkan Pribadi Muslim Nusantara yang mencintai Islam, berkomitmen penuh pada Negara Kesatuan Republik Indonesia (NKRI), bertoleransi dalam keberagaman, menghargai kemajemukan, dan selalu menebarkan perdamaian.

SMP Islam As-Syafi'ah Mojosari juga ikut andil dalam melakukan pembentukan karakter Muslim Nusantara yang sesuai dengan ajaran Islam yang berpadu dengan nilai-nilai tradisi, budaya dan kearifan lokal pada semua sisi kehidupan, sehingga melahirkan Pribadi Muslim Nusantara yang mencintai Islam, berkomitmen penuh pada Negara Kesatuan Republik Indonesia, bertoleransi dalam keberagaman, menghargai kemajemukan, dan selalu menebarkan perdamaian.

\section{Kesimpulan}

Berdasarkan hasil penelitian kualitatif dengan teknik observasi, wawancara, dan dokumentasi di SMP Islam As-Syafi'ah Mojosari penulis memberikan kesimpulan sebagai berikut: Model Pembelajaran berbasis pesantren yang di implementasikan di SMP Islam As-Syafi' ah Mojosari berjalan dengan tidak merubah khas pesantren. Semua kegiatan dilaksanakan semua 
santri yang juga menjadi peserta didik di SMP Islam As-Syafi'ah. Selain program wajib mondok juga ada program tahfidz dan kewirausahaan. Program tahfidz yang dimaksud adalah wajib hafal alQur'an Juz 30 dan dianjurkan untuk menghafal semua al-Qur'an

\section{Daftar Pustaka}

Ali, Mukti. Beberapa Persoalan Agama Dewasa Ini, Jakarta: Rajawali Press, 1987

Burden, P. R., \& Byrd, D. M. Method for effective teaching, second edition. Boston: Allyn and Bacon 1996.

Dhofier, Zamakhsyari. Tradisi Pesantren (Studi Pandangan Hidup Kyai dan Visinya mengenai Masa Depan Indonesia, Jakarta, LP3ES, 1982

Gunter, M. A., Estes, T. H., \& Schwab, J. Instruction: A models approach. Boston: Allyn and Bacon (1990).

H.M. Arifin, Kapita Selekta Pendidikan Islam, Jakarta: Bumi Aksara, 2003

Hasbullah, Sejarah Pendidikan Islam Indonesia, Jakarta: PT. Grafindo Persada, 1996

Hasbullah, Sejarah Pendidikan Islam Indonesia, Jakarta: PT. Grafindo Persada, 1996

Hasbulloh, Kapita Selekta Pendidikan Islam, Jakarta: PT. Raja Grafindo Persada, 1999

https://www.e-

dokumen.kemenag.go.id. Di akses pada tanggal 15 maret 2018
Khairir, M. Integrasi metode Sarongan dan Bandongan dalam meningkatkan kreativitas belajar dipondok pesantren Aswaja-MlangiSleman, Yogyakarta) Yogyakarta: Universitas Islam Negeri, 2013

Madjid, Nurcholis. Bilik-Bilik Pesantren Sebuah Potret Perjalanan, Jakarta: Paramadina. 1997

Suprawan, Dedi dan Surasega, A. Benyamin. Strategi Belajar Mengajar, Diktat Kuliah, FPTK-IKIP: Bandung, 1990

Triatno, Mendesain Model Pembelajaran Inovatif-Progresif, Jakarta: Kencana, 2011

Wahyoetomo, Perguruan Tinggi Pesantren (Pendidikan Alternatif Masa Depan), Jakarta: Gema Insani Press, 1997

Wirawan, "Teori-teori sosial dalam tiga paradikma fakta sosial,definisi sosial,perilaku sosial," Jakata: Kencana prenada media Grouph, 2012 